
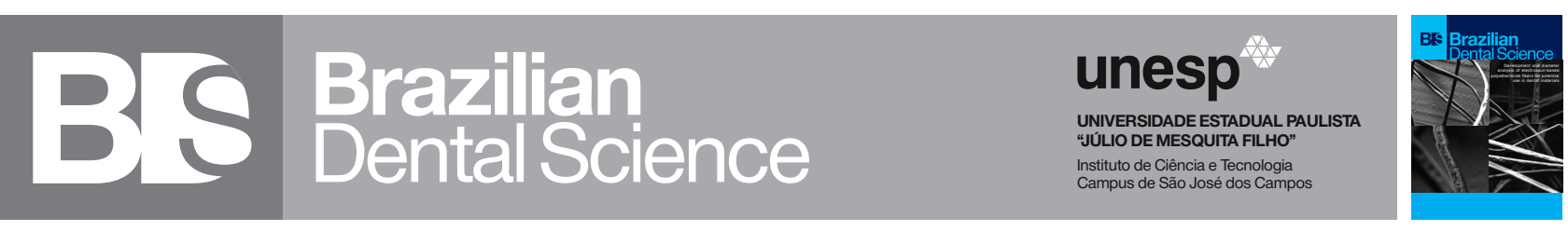

\title{
Development of electrospun-based polyetherimide fibers and diameter analysis for potential use in dental materials
}

Desenvolvimento de fibras de polieterimida à base de eletrofiação e análise de diâmetro para uso potencial em materiais odontológicos

Elisa Camargo KUKULKA ${ }^{1}$, Tabata Prado SATO ${ }^{1}$, Karen Cristina ARCHANGELO ${ }^{1}$, Jéssica Dias SANTOS ${ }^{1}$, Joyce Rodrigues de SOUZA ${ }^{1}$, Alexandre Luiz Souto BORGES ${ }^{1}$

1 - Institute of Science and Technology of Sao Jose dos Campos, São Paulo State University (UNESP), Sao Jose dos Campos, Brazil.

\section{ABSTRACT}

Objetives: this study aimed to fabricate electrospun-based polyetherimide (PEI) fibers, under controlled parameters, and to perform a diameter analysis for potential mechanical improvement of dental materials. Material and Methods: PEI pallets (0.75 g) were dissolved in $2 \mathrm{~mL}$ of chloroform and then processed by electrospinning, under a flow rate of $1 \mathrm{mLh}^{-}$ ${ }^{1}$, three different electrical voltages $(10 \mathrm{kV}$, $15 \mathrm{kV}$ and $20 \mathrm{kV})$ and three distances $(10 \mathrm{~cm}$, $15 \mathrm{~cm}$ and $18 \mathrm{~cm}$ ) between the needle tip and collector. These parameter combinations resulted in nine experimental groups that were analyzed using scanning electron microscopy (SEM) and image processing program for diameter measurement. Statistical analysis was performed using two-way ANOVA with post-hoc Tukey (5\% significance). Results: from SEM images it was possible to observe formation of solid, misaligned and flawless defect-free fibers. And from the statistical analysis, distance $(\mathrm{p}=0,0026)$ and the electric tension ( $\mathrm{p}=0,0012)$ showed a significant difference, but not for interaction between then $(\mathrm{p}=0,4486)$. Conclusion: thus, it can be concluded that there is a possibility of the morphology control of PEI electrospun fibers, such as diameter, that can be used for a variety of applications such as incorporation in dental materials in order to improve its properties.

\section{KEYWORDS}

Electrospinning technique; Fibers; Polyetherimide; Polymer.

\section{RESUIMO}

Objetivos: o objetivo deste estudo foi fabricar fibras de polieterimida à base de eletrofiação (PEI), sob parâmetros controlados, e realizar uma análise de diâmetro para potencial aprimoramento mecânico de materiais odontológicos. Material e métodos: paletes de PEI $(0,75 \mathrm{~g})$ foram dissolvidos em $2 \mathrm{~mL}$ de clorofórmio e processados pela eletrofiação, sob uma razão de fluxo de $1 \mathrm{mLh}^{-1}$, três tensões elétricas diferentes $(10 \mathrm{kV}, 15 \mathrm{kV}$ e $20 \mathrm{kV})$ e três distâncias $(10 \mathrm{~cm}, 15 \mathrm{~cm}$ e $18 \mathrm{~cm})$ entre a ponta da agulha e o coletor. Essas combinações de parâmetros resultaram em nove grupos diferentes que foram analisadas usando microscopia eletrônica de varredura (MEV) e programa de processamento de imagem para medição de diâmetro. Resultados: a partir das imagens de MEV foi possível observar a formação de fibras sólidas, desalinhadas e sem defeitos. E a partir da análise estatística, a distância $(\mathrm{p}=0,0026)$ e a tensão elétrica $(\mathrm{p}=$ 0,0012) apresentaram diferença significativa, mas não para interação entre elas ( $\mathrm{p}$ = 0,4486). Conclusão: assim, pode-se concluir que existe a possibilidade de controle da morfologia das fibras eletrofiadas PEI, como o diâmetro, que pode ser utilizado para uma variedade de aplicações, como incorporação em materiais dentários, a fim de melhorar suas propriedades.

\section{PALAVRAS-CHAVE}

Técnica de eletrofiação; fibras; polieterimida; polímero. 


\section{INTRODUCTION}

S everal materials have been used in restorative dentistry [1] and decisionmaking for the best material for each clinical situation is essential, based on the aesthetic aspects, but also the mechanical properties, longevity and functional rehabilitation provided by the material [2].

In order to improve restorative materials properties, composite resins, fiber-reinforced resin, polymeric matrix reinforced were introduced in dental material context $[3,4]$. In this sense, properties such as the mechanical performance of these materials can be resulted from a combination of the characteristics of the fiber and the matrix. Thus, variables such as amount of fibers incorporated, the efficiency of adhesion with the material matrix and fiber diameter are important for the final balance of the material properties [5-7].

Currently, polymeric fibers obtained by the electrospinning technique have been associated with increased resistance of resinous materials [8]. Electrospinning is based on the application of an electrical force on polymeric solution promoting the ejection of a fine jet that is elongated and dried, deposited on a substrate [9].

The morphology of these fibers is controlled and depends on several parameters such as solution conductivity, solution surface tension, polymer content, polymer molecular weight, viscosity and applied voltage [10]. In addition, the chemical interaction between the organic matrix of the resin, for example, and the reinforcement material must be functionalized to achieve an advantageous reinforcement effect [11].

A polymer widely studied is Polyetherimide (PEI), an amorphous thermoplastic polymer with excellent properties that include: high mechanical resistance, thermal and chemical stability. Its properties are compared with metallic and ceramic materials for its elasticity, toughness, impact and abrasion resistance, good insulation and chemical resistance and exposure to time [12].

In this sense, the study of polymeric fibers for material reinforcement becomes relevant. Thus, the aim of the present study was to fabricate and to characterize diameter of electrospunbased polyetherimide fibers, under controlled parameters, for potential improvement of dental material properties.

\section{MATERIALS AND METHODS}

\section{Synthesis of fibers}

To obtain the fibers, a polymeric solution obtained by dissolving $0.75 \mathrm{~g}$ of PEI (Sigma Aldrich, Saint Louis, USA) in $2 \mathrm{~mL}$ of chloroform (Synth, São José dos Campos, Brazil) was used. The solution was taken to the magnetic stirrer and maintained for 24 hours.

Then, electrospinning was perfomed with high voltage source $(10 \mathrm{kV}, 15 \mathrm{kV}$ and $20 \mathrm{kV})$, an infusion pump for flow control $\left(1 \mathrm{mLh}^{-1}\right)$, plastic syringe with a straight needle $(\varnothing 0.7$ $\mathrm{mm}^{2}$ ) and static collector apparatus covered with thin aluminum foil $(0.2 \mathrm{~mm})$. And distance from the tip of the needle to the collecting apparatus ranging from $10 \mathrm{~cm}, 15 \mathrm{~cm}$ and 18 $\mathrm{cm}$, generating 9 morphological patterns of fibers (Table I).

Table I - Parameters of study and experimental groups

\begin{tabular}{ccccc}
\multicolumn{5}{c}{ Electric Tension } \\
& \multicolumn{5}{c}{$\mathbf{1 0 k V}$} & $\mathbf{1 5 k V}$ & $\mathbf{2 0 k V}$ \\
\hline \multirow{3}{*}{ Distance } & $\mathbf{1 0 c m}$ & G1 & G2 & G3 \\
& $\mathbf{1 5 c m}$ & G4 & G5 & G6 \\
& $\mathbf{1 8 c m}$ & G7 & G8 & G9
\end{tabular}

A standardized time of 5 min was used for the collection of fibers for each combination of variables. After collecting the fibers, they were stored in a desiccator for 48 hours to evaporate the remaining solvent. 


\section{FIBER CHARACTERIZATION}

\section{Scanning Electron Microscopy (SEM)}

Specimens of $0.5 \times 0.5 \mathrm{~cm}$ of the aluminum foil of each morphological pattern generated from the fibers were covered with gold and analyzed using scanning electron microscopy (SEM) to assess the morphology, alignment, diameter and quantity of fibers generated.

Electrospun nanofibers micrographies were obtained using the Scanning Electron Microscope With high-vacuum equipment (Inspect S 50, FEI Company, Brno, Czech Republic) operating at $20-25 \mathrm{KV}, 5.0$ spot and magnifications of 500x.

\section{Measurement of fiber diameter}

The diameter analysis was performed using the Image $\mathrm{J}$ software (image analysis software, Version $1.44^{\circ}$, National Public of Health), by which 30 measurements were collected in each image of the generated patterns to obtain the average diameter in nanometers, standard deviation and coefficient of variation. Descriptive statistical analysis used mean and standard deviations values and two independent variables (distance and electric tension). Then two-way ANOVA with post-hoc Tukey (5\% significance) was performed.

\section{RESULTS}

\section{Scanning Electron Microscopy (SEM)}

Parameter combinations resulted in nine experimental groups of fibers that were analyzed in SEM and from Figure 1 it was possible to observe formation of solid, misaligned and flawless fibers.

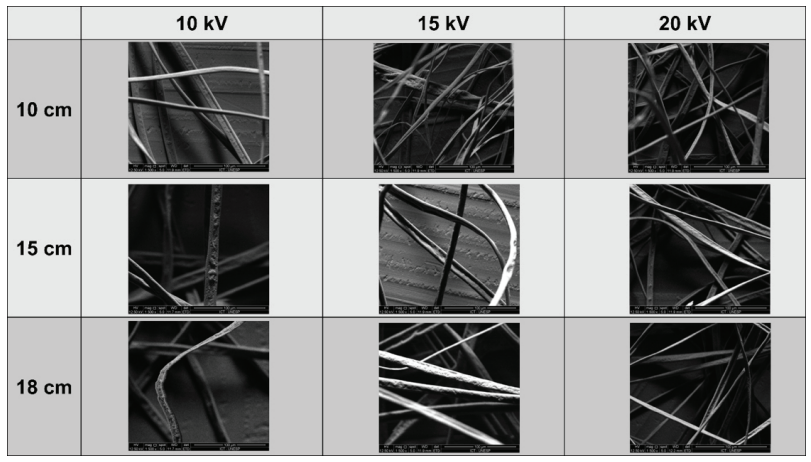

Figure 1 - SEM images from experimental groups obtained from parameter combinations.

\section{Measurement of fiber diameter}

From the statistical analysis of the data obtained, distance ( $\mathrm{p}=0,0026)$ and the electric tension ( $p=0,0012)$ showed a significant effect, but the distance/electric tension interaction ( $\mathrm{p}=0,4486)$ did not. Table II shows all the experimental groups.

Table II - The mean fiber diameter (and standart desviation) of experimental groups as a function of the Distance and Voltage

\begin{tabular}{|cccc|}
\hline GROUP & Mean $\pm \mathbf{S D}(\boldsymbol{\mu m})$ & Distance $(\mathbf{c m})$ & Voltage $(\mathbf{k V})$ \\
\hline G1 & $6,39 \pm 1,98^{\mathrm{a}}$ & 10 & 10 \\
\hline G2 & $10,28 \pm 3,04^{\mathrm{b}}$ & 10 & 15 \\
\hline G3 & $11,83 \pm 6,06^{\mathrm{c}}$ & 10 & 20 \\
\hline G4 & $2,99 \pm 1,31^{\mathrm{d}}$ & 15 & 10 \\
\hline G5 & $8,81 \pm 1,70^{\mathrm{a}}$ & 15 & 15 \\
\hline G6 & $7,56 \pm 5,0^{\mathrm{a}}$ & 15 & 20 \\
\hline G7 & $3,88 \pm 1,39^{\mathrm{a}}$ & 18 & 10 \\
\hline G8 & $4,67 \pm 1,84^{\mathfrak{a}}$ & 18 & 15 \\
\hline G9 & $7,30 \pm 2,24^{\mathrm{a}}$ & 18 & 20 \\
\hline
\end{tabular}

* Different letters indicate significant statistical difference.

The two-way ANOVA results revealed in Figure 2 the multiple comparisons of the experimental groups 


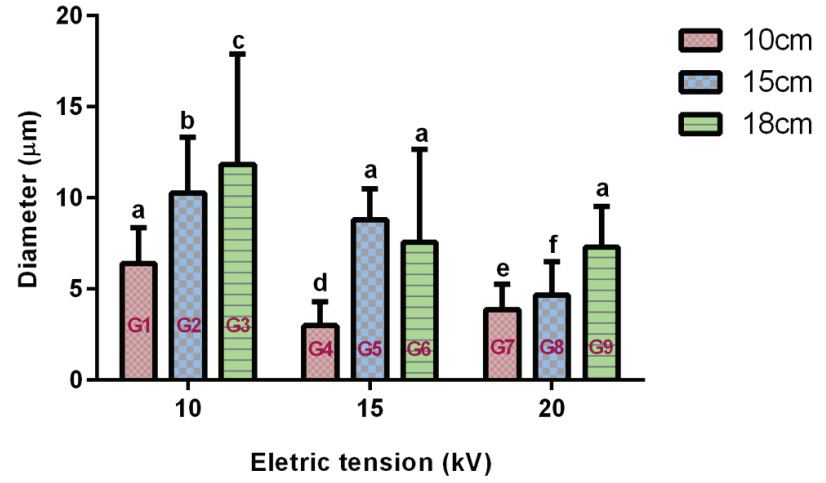

Figure 2 - Statistical distribution of the nanofiber diameters generated by different electrospinning parameters.

\section{DISCUSSION}

Several polymers are used for electrospinning process such as Chitosan [13], Polycaprolactone [14] and Polyetherimide (PEI) [15]. PEI presents similar advantages to metals, biocompatibility, corrosion resistance [16] highly thermal-resistant [17] and excellent mechanical properties [18].

PEI fibers were produced, for the present study, to obtain an ideal pattern for potential improvement of dental materials properties, as already used for composite and acrylic resins [19]. It was possible to obtain nine distinct morphological types of electrospun fibers by the interaction of two variable parameters (electric tension and distance between the needle tip and collector).

The different fiber diameters (Figures 2) obtained can be explained by the electrospinning process parameters that changed the production pattern $[13,20]$ that corroborates the significant statistical results of distance $(p=0,0026)$ and the electric tension $(\mathrm{p}=0,0012)$. Several studies suggested a controversial influence of the applied voltages on the diameter fibers which higher voltages can facilitate larger diameters [21] or that there is not much effect of electric field [22]. In this study, G4 group (10 $\mathrm{cm} / 15 \mathrm{kV})$ resulted smaller diameters $(2,99$ $\pm 1,3 \mu \mathrm{m})$ instead $\mathrm{G} 3(18 \mathrm{~cm} / 10 \mathrm{kV})$ with the larger diameters $(11,83 \pm 6,06 \mu \mathrm{m})$ without interaction between factors.

In this context, the fibers diameter analysis is important for the properties that will be incorporated into the matrix of the materials since they can influence roughness [23] and mechanical strength [24]. Although there are some studies on the effects of fiber diameter on tensile properties $[25,26]$ and some revealed an inverse correlation between the tensile strength and the fiber diameter [27], the decision of which best characteristic for a reinforcement material depends on the expected application for the final product.

Thus, from the production of PEI fibers it was possible to observe that the technique used was satisfactory with determined parameters, however studies are still necessary in order to optimize the production of the obtained fibers.

\section{CONCLUSION}

Based on the results, it can be concluded that there is a possibility of the morphology control of PEI electrospun fibers, such as diameter, that can be used for a variety of applications such as incorporation in dental materials in order to improve its properties. For future experiments the indicated group is G4 $(10 \mathrm{kV}$ and $15 \mathrm{~cm})$ for obtaining the smallest diameter and standar deviation. Thus, further studies are necessary for evaluation of tensile strength, in order to support the results of this work aiming future application in dentistry.

\section{REFERENCES}

1. Moraschini V, Fai CK, Alto RM, Dos Santos GO. Amalgam and resin composite longevity of posterior restorations: A systematic review and meta-analysis. J Dent. 2015 Sep;43(9):1043-50. doi:10.1016/j.jdent.2015.06.005.

2. Ali Z, Eliyas S, Vere JW. Choosing the right dental material and making sense of the options: evidence and clinical recommendations. Eur JProsthodont Restor Dent. 2015 Sep;23(3):p.150-62.

3. Khan AS, Azam MT, Khan M, Mian SA, Ur Rehman I. An update on glass fiber dental restorative composites: a systematic review. Mater Sci Eng C Mater Biol Appl. 2015 Feb;47:26-39. doi: 10.1016/j.msec.2014.11.015. 
4. Santos JD, Sato TP, Lima AL de, Nogueira AS, Quishida CCC, Borges ALS Titanium Dioxide and Polyethylmethacrylate electrospun nanofibers: assessing the technique parameters and morphological characterization Braz Dent Sci. 2019:22(1). doi: https://doi.org/10.14295/bds.2019.v22i1.1630

5. Zhang M, Matinlinna JP.E-Glass fiber reinforced composites in dental applications. Silicon. 2012;4(1):73-8.

6. Sato N, Kurauchi T, Sato S, Kamigaito O. Reinforcing Mechanism by Small Diameter Fiber in Short Fiber Composite. J Compos Mater. 1988;22(9):85073.

7. Thomason JL. The influence of fibre length, diameter and concentration on the impact performance of long glass-fibre reinforced polyamide 6,6. Compos Part A Appl Sci Manuf. 2009;40(2):114-24. doi: https://doi. org/10.1016/j.compositesa.2008.10.013

8. Uyar T, Çökeliler D, Dołan M, Koçum IC, Karatay 0, Denkbaş EB. Electrospun nanofiber reinforcement of dental composites with electromagnetic alignment approach. Mater Sci Eng C Mater Biol Appl. 2016 May;62:762-70. doi:10.1016/..msec.2016.02.001.

9. Reneker DH, Yarin AL. Electrospinning jets and polymer nanofibers. Polymer 2008;49(10):2387-2425.doi:https://doi.org/10.1016/.jpolymer.2008.02.002

10. Moon S, Choi J, Farris RJ. Preparation of aligned polyetherimide fiber by electrospinning. J Appl Polym Sci. 2008;109(2):691-4.

11. Borges ALS, Münchow EA, de Oliveira Souza AC, Yoshida T, Vallittu PK, Bottino MC. Effect of random/aligned nylon-6/MWCNT fibers on dental resin composite reinforcement. J Mech Behav Biomed Mater.2015 Aug;48:134144. doi: 10.1016/.j.jmbbm.2015.03.019

12. Johnson RO, Burlhis HS. Polyetherimide: A new high-performance thermoplastic resin. J Polym Sci Polym Symp [Internet]. 2007;70(1):129-43. Available from:http://doi.wiley.com/10.1002/polc.5070700111

13. De Souza JR, Sato TP, Borges ALS. Scaffold architecture for dental biomaterials: influence of process parameters on the structural morphology of chitosan electrospun fibers. Braz Dent Sci. 2017;20(4):100. doi: https://doi. org/10.14295/bds.2017.v2014.1495

14. Silva JR, Sato TP,Borges ALS. Synthesis and morphological characterization of polycaprolactone (PCL) membranes with tara extract (caesalpinia spinosa). Braz Dent Sci. 2019;22(2). doi: https://doi.org/10.14295/bds.2019 v22i2.1688
15. Al-Ghafri B, Lau WJ, Al-Abri M, Goh PS, Ismail AF. Titanium dioxide-modified polyetherimide nanofiber membrane for water treatment. JWater Process Eng.2019;32. doi:https://doi.org/10.1016/j.jwpe.2019.100970

16. Kostopoulos V, Kotrotsos A, Fouriki K, Kalarakis A, Portan D. Fabrication and characterization of polyetherimide electrospun scaffolds modified with graphene nano-platelets and hydroxyapatite nano-particles. Int J Mol Sci. 2020 Jan 16;21(2):583. doi: 10.3390/jims21020583.

17. BagheriH, Akbarinejad A, Aghakhani A. A highly thermal-resistant electrospun-based polyetherimide nanofibers coating for solid-phase microextraction. Anal Bioanal Chem. 2014 Mar;406(8):2141-9. doi:10.1007/ s00216-013-7407-y.

18. Tang $X$, Qin $Y, X u X, G u o ~ D, Y e$ W, Wu W, Li R. Fabrication and in vitro evaluation of $3 \mathrm{~d}$ printed porous polyetherimide scaffolds for bone tissue engineering. Biomed Res Int. 2019 Nov 11;2019:2076138. doi: 10.1155/2019/2076138

19. Girotto B. Influência da incorporação de nanofibras de poliamida 6 come sem nanotubos de carbono como reforço de prótese parcial fixa adesiva [tcc]. São José dos Campos (SP): Universidade Estadual Paulista (Unesp), Faculdade de Odontologia de São José dos Campos; 2015.

20. LiD, Xia Y.Electrospinning of Nanofibers: Reinventing the Wheel? Adv Mater. 2004;16(14):1151-70.doi: https://doi.org/10.1002/adma.200400719

21. Zhang C, Yuan X, Wu L, Han Y, Sheng J. Study on morphology of electrospun poly(vinyl alcohol) mats. Eur Polym J. 2005;41(3):423-32.

22. Reneker DH, Chun I. Nanometre diameter fibres of polymer, produced by electrospinning. Nanotechnology. 1996;7(3)

23. Milleret V, Hefti T, Hall H, Vogel V, Eberli D. Influence of the fiber diameter and surface roughness of electrospun vascular grafts on blood activation. Acta Biomater.2012 Dec;8(12):4349-56. doi:10.1016/.jactbio.2012.07.032

24. Wong SC, Baji A, Leng S. Effect of fiber diameter on tensile properties of electrospun poly( (ع-caprolactone). Polymer (Guildf). 2008;49(21):4713-22.

\section{Tabata Prado Sato}

(Corresponding address)

Institute of Science and Technology of São Jose dos Campos, São Paulo State University

(UNESP), Sao Jose dos Campos, Brazil

Email: tabata.sato@unesp.br

Date submitted: 2020 Mar 26

Accept submission: 2020 Sep 08 